MORE MONEY F F $^{r} \mathrm{R}$ THE PUBLIC SCHOOLS

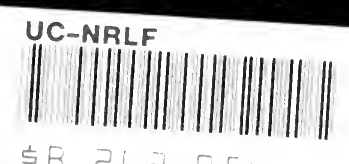




\section{LIBRARY}

OF THE

UNIVERSITY OF CALIFORNIA.

Class. 
$+$

1

te 

More Money for the Public Schools 



\title{
MORE MONEY FOR THE PUBLIC SCHOOLS
}

\author{
BY \\ CHARLES W. ELIOT
}

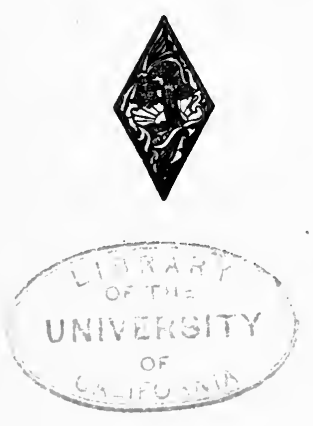

NEW YORK

DOUBLEDAY, PAGE \& COMPANY 1903 


$$
\begin{gathered}
\text { LA } 216 \\
E 42
\end{gathered}
$$

Copyright, 1903, by Doubleday, Page \& Company Published, April, 1903

$$
\text { of log? }
$$


More Money for the Public Schools, Because of the Failures and Shortcomings in American
Education

[An address before the Connecticut State Teachers' Association on October 17, 1902.] 


\section{Digitized by the Internet Archive in 2007 with funding from \\ Microsoft Corporation}


MORE MONEY FOR THE PUBLIC SCHOOLS

T $\mathrm{Y}$ object in this paper is to urge that the expenditure per pupil in the common schools of the

United States is altogether insufficient. As foundation for my argument, I must first state what the annual expenditure per pupil now is. For this purpose I avail myself of the table of annual expenditure per pupil which is to appear in Commissioner Harris's Report for I900-I90I, an advance copy of which has kindly been given me.

The average expenditure per pupil 


\section{Shortcomings of American Education}

for the whole school year in the United States was then $\$ 2$ I. I 4 ; but this expenditure varies very much in the different divisions of the country. Thus the average expenditure per pupil in the North Atlantic Division of the United States is $\$ 33.5^{2}$, while in the South Central Division it is only $\$ 7.54$. It also varies very much in the different States of the Union. Thus the highest expenditure is made in New York, namely, $\$ 41.68$; the next highest in the District of Columbia, $\$ 40.50$; the next highest in Nevada, $\$ 39.70$; the next in Colorado, $\$ 38.29$; the next in Massachusetts, \$38.2 I. On the other hand, the lowest expenditures occur in the South Atlantic and the South Central Divisions, North Carolina spending 
Average Expenditure Per Pupil 5

annually $\$ 4.56$ per pupil; Mississippi, $\$ 6.48$; Georgia, $\$ 6.68$. The Western Division (which includes the Pacific Coast) has in general a high average expenditure per pupil, coming next to the North Atlantic Division.

This total average expenditure for the year being divided by the average number of days during which schools are kept in the several divisions or States (that is, by the average length of the school term in days), yields another interesting figure, namely, the average daily expenditure per pupil. For the whole United States this average daily expenditure in 1900-r90I was 14.7 cents; but again the range of the average daily expenditure per pupil is large. The Western, or Rocky Mountain and 
6 Shortcomings of American Education

Pacific, Division pays most per pupil per day, namely, 22 cents; the North Atlantic Division pays I8.9 cents daily for each pupil; whereas the South Atlantic Division pays but 8.6 cents, and the South Central but 7.8 cents. The highest daily expenditures per pupil occur in the Western Division. Thus Montana spends 27.9 cents per day; Colorado, 25.8 cents; Nevada, 25.6 cents; whereas the District of Columbia spends 23 cents; Massachusetts, 20.7 cents; New York, 22.4 cents. Here, again, the South Atlantic Division and the South Central Division present the lowest figures. Maryland spends 9.9 cents per pupil per day; Virginia, 8.2 cents; North Carolina and Georgia, 6 cents; South Carolina, 5.3 cents; 
Percentage Expenditure on Salaries 7

Louisiana, 7.3 cents; Arkansas, 8.2 cents.

Still another instructive figure is the percentage of the total school expenditure which is devoted to salaries. In the country the expenditures on sites for buildings are nothing, or very small; in cities the expenditures for this purpose are necessarily heavy. Again, the miscellaneous expenses vary much in different localities; so that it is interesting to see what percentage of the total expenditure in any division of the country, or in any State, goes to salaries. This figure is far less variable than the figures I have already quoted. In the United States as a whole the percentage of the total school expenditure devoted to salaries is 63.2 ; in the different divisions 
8 Shortcomings of American Education

of the United States the percentage varies from 57.2 in the North Atlantic Division to 83.6 in the South Central Division, this Division, which makes a very small total expenditure per pupil, namely, \$7.54, devoting 83.6 per cent. of this total expenditure to salaries. The State of New York, on the other hand, which has numerous large cities within its borders, devotes only 59.I per cent. of its total school expenditure to salaries; because it is obliged to spend on sites and buildings nearly a quarter of its total annual output. The District of Columbia is in the same situation; and in Massachusetts only 60 per cent. of the total expenditure goes for salaries. Among the States it is curious to observe that the 
largest percentages for salaries occur in the least advanced States; thus Nevada gives 83.4 per cent. to salaries; Arkansas, 85.I; Texas, 88.I; South Carolina, 86.7.

Another fact which throws light on the present situation of the American child of school age is the length of the school term in the different parts of our country. The average length seems to be I44 days; but this figure is only approximate, and needs interpretation, or at least an understanding of the methods of computation by which it is obtained. It indicates, however, that the average school term does not exceed twenty-fiye to thirty weeks in the year. Another figure which has great interest is the average number of days of. 
ro Shortcomings of American Education

schooling provided during the year for every child from five to eighteen years of age. This number of days is supposed to be 68.3 in the United States as a whole. In the different divisions this figure varies from forty-one and a fraction in the South Atlantic and South Central Divisions to 87.5 in the North Atlantic Division. These last figures are taken from Commissioner Harris's Report for 1899-1900. The report is careful to point out the uncertainty which affects the figures, in consequence of the incompleteness of the returns, and of the different methods employed in different States for computing these results. For my present purpose it is safe to regard them as a rough approximation to the actual facts. 
While these figures are in your minds, let me ask attention to the common practice of including the cost of school sites and buildings in the so-called school expenditure of the year. Thus, in the State of New York, nearly a quarter of what was called the school expenditure in r900-'or went to sites and buildings; and in New Jersey, Minnesota, Kansas and Washington more than a quarter. It seems to me that a method of accounting should be used which would not seem to throw this sort of expenditure or any part of it on the school resources of a single year. When a city obtains a new water-supply, or makes important additions to its old one, or builds a new city hall or a costly bridge, it meets the outlay by an 
I2 Shortcomings of American Education issue of long bonds, which really spreads the expenditure over many years. When the Boston Metropolitan District wanted parks, and spent $\$ 10,000,000$ in procuring them, it was at pains to spread the original expenditure for those parks over many years. The same method would be perfectly just in regard to school sites and school buildings. These are expenditures made for future generations, as well as for the present; or, rather, they are made in much larger proportion for the benefit of the future than of the present. While, therefore, everything which relates to the maintenance of schools, as of parks or watersupplies, should be chargeable as expenditure of the current year, outlays for new sites and buildings ought not to 
Construction Is Not Maintenance I 3

appear in the annual school accounts. At the outside, only interest and sinkingfund charges on such outlays ought to appear in the annual accounts. In studying the total annual school expenditure per pupil in any one community, and particularly in making comparisons between different communities in regard to school outlays, it is important to bear in mind this too common practice of including expenditures for sites and buildings in the reported annual school expenditure per pupil. Thus the District of Columbia is reported as spending \$40.50 per pupil per year; but the significance of this figure is considerably modified by the fact that in r900-I90I \$9.54 out of this sum went for sites and buildings. The 
I4 Shortcomings of American Education individual child going to school in the District had only $\$ 30.96$ spent on its education. That child's privileges were determined by the existing school plant and the outlay in that year for salaries, equipment, and maintenance. In Colorado in that same year the actual present child got $\$ 32.93$ out of a total expenditure of $\$ 38.29$. It is hardly any object for a town or city to keep an open account of its expenditures for its school plant, for the reason that it is impossible to compute the return from that investment. A portion of the return from park expenditures can be computed-namely, the rise in the valuations of the neighbouring private lands or lots; but the best part of the return-the increased health and happi- 
ness of the population-cannot be estimated in money. Water-supplies yield an income in a proper financial sense, so that it is worth while to keep an account with them as municipal investments. Not so with school plants - the return on them being beyond the reach of computation.

Let us now compare the annual expenditure on the public school child with what is made by a well-to-do family on its child sent to an endowed or a private school. In many American cities it is now the private school which receives the children of well-to-do parents; and this school charges a tuition fee of from $\$ 100$ to $\$ 500$ a year for day pupils. You may suppose that the higher fees are paid in cities like New York and 
I6 Shortcomings of American Education

Philadelphia; but the highest fee that I know for a day pupil is charged by a private school at Louisville-namely, $\$ 500$ a year. The endowed secondary schools are mostly situated in the country or in small towns; and in these boarding-schools the total charge for the year per pupil may be said to vary between $\$ 400$ and $\$ 1,000$. Now, it is perfectly easy to provide lodging and food for any pupil between the age of ten and eighteen at a cost of $\$ 5$ a week; so that the charge for tuition and general care, and sometimes interest on the plant, at these institutions must be from $\$ 200$ to $\$ 600$ a year of forty weeks. It is fair to state that some of the more expensively endowed schools make an elaborate and costly provision 
for the physical training of their pupils and their outdoor sports. For the public school child no such provision is ordinarily made. If you ask on what these large annual fees are expended, the answer is chiefly on teaching. A public school which has a teacher for every forty pupils is unusually fortunate; the private and endowed schools of the country not infrequently provide a teacher for every eight or ten pupils. Moreover, they employ a more expensive kind of teacher; for they use as teachers a larger proportion of men, and a larger proportion of college graduates, both men and women. For children of from six to ten years of age there is a very similar disproportion between the fee in private schools and the expendi- 
I8 Shortcomings of American Education ture per pupil in the public schools; thus private kindergartens not infrequently charge \$100 a year for each child, and in private country schools for young children the charges approach those made in the private or endowed secondary schools.

The practice of employing tutors and governesses in single families is constantly increasing in the United States, and it is noteworthy that salaries are often paid to persons so employed which are decidedly higher than the salaries paid public school teachers, although they may have charge of only three or four children, or sometimes of a single child.

I cite these figures simply to show that well-to-do Americans, who can 
Families Pay Freely for Education is

afford to spend on the education of their children whatever seems advantageous, are ready to spend liberally for their children's education. It is not necessary to my argument to assume that the expenditures thus made by well-to-do families are always judicious; an expensive private or endowed school may have serious drawbacks, which offset some of its obvious advantages; but the figures I have cited show what thousands of American parents think it their interest to spend on the educa- . tion of their children; and these thousands, belonging to the families most successful pecuniarily, probably represent the more intelligent and far-seeing families. I, of course, have not in mind the excessively rich; because their task 
20 Shortcomings of American Education

in educating their children is made infinitely more difficult by the very fact of their excessive riches. I have in mind the ordinary, successful, professional man or business man, who earns money enough in a year to be able to afford for his children the best training he knows how to give them.

Compare now a tuition fee of from $\$ 100$ to $\$ 600$ with the annual expenditure on the public school child in the most liberal States; with the expenditure, for instance, of $\$ 30$ per child per year in Massachusetts, or of $\$ 32$ in New York, after deducting in both instances from the total expenditure the cost of sites and buildings. Compare these high tuition fees again with the total expenditure per child and per year of $\$ 4.32$ in 
Multiplying School Cost by Five 2 I

South Carolina, or of $\$ 8.32$ in Kentucky, or of $\$ 9.77$ in Texas-the expenditures on sites and buildings being in each case deducted from the total expenditure. Is it not plain that if the American people were all well-to-do they would multiply by four or five the present average school expenditure per child and per year? That is, they would make the average expenditure per pupil for the whole school year in the United States from $\$ 80$ to $\$ 100$ for salaries and maintenance, instead of $\$ 17.36$ as now. Is it not obvious that instead of providing in the public schools a teacher for forty or fifty pupils, they would provide a teacher for every ten or fifteen pupils? Would there not be a playground around every schoolhouse? If 
22 Shortcomings of American Education

the American people thought they could afford it, would not a schoolhouse be kept in as perfect sanitary condition as a hospital? Fifty years ago nobody knew how to keep either a schoolhouse or a hospital in a wholesome state; now we do know how, and the hospitals are kept safe, but the schoolhouses are not. I wish to urge on you the proposition that the American people cannot afford to persist in the present low school expenditure per pupil and per year.

It appears from the table herewith that of the twenty largest American cities one spends less for schools than for police; thirteen spend less than twice as much for schools as for police; four spend less than two and a quarter times as much for schools as for police; one spends three times as much, and one three and four-tenths times as much. These ratios are remarkable, considering that police, however indispensable, only protect the community partially from crimes, disorders, and nuisances-that is, from the grossest forms 
of evil-while schools build up in intelligence and character the human constituents of the future community itself. This table was prepared at the instance of Professor Calvin M. Woodward, of St. Louis, by the Bureau of Education at Washington, which relied for the facts concerning the police departments on Bulletin No. 42 of the Department of Labor, September, I902. Professor Woodward (for a local purpose which was promptly fulfilled) recast the table; and it is his form which is given on page 24 .

My first argument in support of this proposition is that, as a nation and on the whole, in spite of many successes, we have met with many failures of various sorts in our efforts to educate the whole people, and still see before us many unsurmounted difficulties. It is indisputable that we have experienced a profound disappointment in the results thus far obtained from a widely diffused popular education. It was a stupen- 


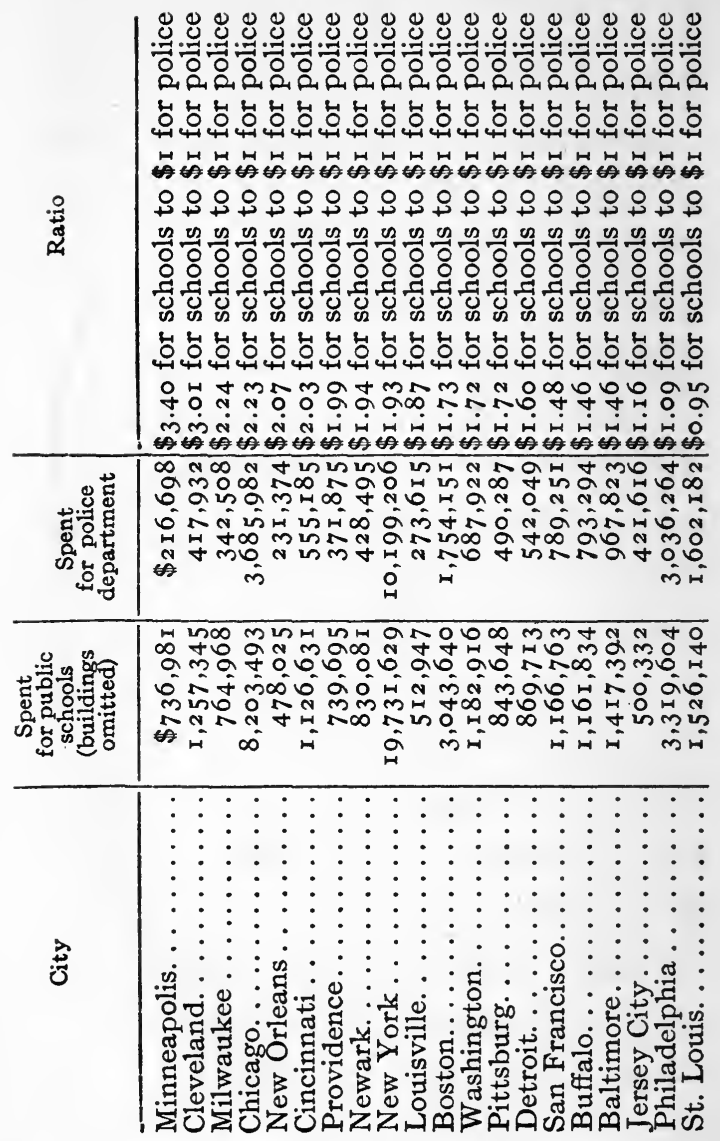


dous undertaking at the start, and the difficulties have increased with every generation. Our forefathers expected miracles of prompt enlightenment; and we are seriously disappointed that popular education has not defended us against barbarian vices like drunkenness and gambling, against increase of crime and insanity, and against innumerable delusions, impostures, and follies. We ought to spend more public money on schools, because the present expenditures do not produce all the good results which were expected and may reasonably be aimed at. I proceed to the unwelcome task of enumerating some of our disappointments with popular education. 
26 Shortcomings of American Education

For more than two generations of men we have been struggling with the barbarous vice of drunkenness, but have not yet discovered a successful method of dealing with it. The United States has dealt with the drinking habits of the people merely as a source of revenue. The legislation of most of the States has been variable, and in moral significance uncertain. In some of the States of the Union we have been depending on prohibitory legislation; but the intelligence of the people has been insufficient either to enforce such legislation or to substitute better. This is an accusation not against the moral disposition of the majority of the people, but against their reasoning power; and it is precisely that reasoning 
power which good schools ought to train. Unquestionably drunkenness has diminished, and the habitual use of strong drink is less common than it was fifty years ago; but it is not the will of the people, as expressed in legislation and the enforcement of legislation, which has brought about this improvement. In an attempt to use the schools as a means of promoting total abstinence from intoxicating drinks a grave injury has been done to the teaching of all the sciences in the schools; because many statements about alcohol, which are not known to be true, and which are apparently contradicted by the common observation of the children themselves, have been forced into the schools. This mode of combatting the tendency to 
28 Shortcomings of American Education use alcoholic drinks has been devised and executed by conscientious women; yet it would be hard to imagine a less intelligent mode. The public schools ought to have made it impossible that benevolence and devotion should be so misdirected. The courts have failed to deal wisely with habitual drunkards as a class, both the theory and the practice of fines and short imprisonments as applied to drunkards being entirely futile.

The persistence of gambling in the United States is another disappointing thing to the advocates of popular education; for gambling is an extraordinarily unintelligent form of pleasurable excitement. It is a prevalent vice among all savage people, but one which a moderate 
cultivation of the intelligence-a very little foresight and the least sense of responsibility-should be sufficient to eradicate. It persists, not only in frontier settlements and mining camps, but in country villages in all parts of the country, and in the large towns and cities. The passion for gambling affects the markets not only for stocks and bonds, but for the great staples of commerce and the necessaries of life. All the competitive sports are damaged by it; and in the forms of betting and of playing games for money even some educated men and women are not ashamed of it.

Next, it must be confessed that the results of universal suffrage are not in all respects what we should have 
30 Shortcomings of American Education

expected from a people supposed to be prepared at school for an intelligent exercise of the suffrage. Our fathers expected that good government would flow from universal suffrage as naturally as the brook flows from its wooded watershed. We have discovered from actual observation that universal suffrage often produces bad government, especially in large cities. The means of popular education are ampler in large cities than they are in the country; but to all appearances the existing urban schools, regarded as means of training voters, cannot contend successfully against the urban influences adverse to the voter's good sense and good will. A striking illustration of the failure of universal suffrage, when 


\section{Unpunished Crimes Abound $3 \mathrm{I}$}

exercised by an uneducated population, was given in the southern states during the period of reconstruction-so called.

It is a reproach to popular education that the gravest crimes of violence are committed in great number all over the United States, in the older states as well as in the newer, by individuals and by mobs, and with a large measure of impunity. The population produces a considerable number of burglars, robbers, rioters, lynchers and murderers, and is not intelligent enough either to suppress or to exterminate these criminals. The immense majority of the population is orderly and peaceable, but lacks the invention or the determination to prevent these incessant violations of its peace. This is a grave 
32 Shortcomings of American Education indictment against popular education in our country. The extinction of these savage crimes against individuals and society would certainly be one result of successful universal education. Again, the nature of the daily reading matter supplied to the American public affords much ground for discouragement in regard to the results thus far obtained by the common schools. It would be easy to point out encouraging symptoms in regard to the reading of the people; but the most obvious phenomenon is that the people consume, and seem to demand, vast quantities of daily reading matter which is coarse, trivial, and unimproving, and in parts even immoral. Since one invaluable result of education is a taste for good 


\section{Masses of Bad Reading Matter 33}

reading, the purchase by the people of thousands of tons of ephemeral reading matter which is not good in either form or substance shows that one great end of popular education has not been attained. Unless the publishers of daily newspapers in all civilized countries are wrong in their judgment of what people demand - which is very unlikelythere is an active demand for a deal of foolish, false, or degrading narrative and fiction. From the point of view of the social philosopher or the ethical reformer this is the worst disappointment of all in regard to the results of the common school education of the nineteenth century.

A similar unfavorable inference concerning popular education may be 


\section{Shortcomings of American Education}

drawn from the quality of the popular theatres of to-day. The popular taste is for trivial spectacles, burlesque, vulgar vaudeville, extravaganza, and melodrama; and the stage often presents to unmoved audiences scenes and situations of an immoral or unwholesome sort. If public education had been mentally and morally adequate, surely the public theatre would be very much better than it is to-day.

Americans are curiously subject to medical delusions; because they easily fall victims to that commonest of fallacies-post hoc, ergo propter hoc. They are the greatest consumers of patent medicines in the known world, and the most credulous patrons of all sorts of "medicine men" and women, and of 
novel healing arts. This mental condition of millions of our countrymen is very discreditable to the common schools; for after reading, writing, and simple ciphering have once been acquired as tools, the very next thing a school should begin to do for its pupils is to teach them the difference between an antecedent event and a true causeor in other words, to impart the power of drawing a just inference. I say the school should begin to do this; because the process is a long one, and is inseparably associated with training in accurate observing and recording. Is it not a just inference from the openness of the American mind to medical delusions that the common schools have not done what they ought to have done toward 


\section{Shortcomings of American Education}

developing in the whole population the power to reason justly?

That labor strikes should occur more and more frequently and be more and more widespread has been another serious disappointment in regard to the outcome of popular education. The whole eastern half of the United States has been forcibly reminded this summer of the stupidity, wastefulness, and ineffectiveness of strikes, considered as remedies for social or industrial wrongs. It should be observed, however, concerning this disappointment, that it results in large measure from a difficulty which accounts for a good many troubles in the United States, namely, the difficulty of assimilating year after year large numbers of foreigners. 


\section{Secrecy or Publicity}

The managers, leaders, and promoters of strikes are frequently foreigners, or persons whose parents came to this country from Europe, and a large proportion of the men who engage in them are of foreign birth. To be sure, it is only a small fraction of the total laboring population of the United States which is organized in laborunions; but this small fraction is active, and possesses in combat the usual advantages which result from compact organization. The labor-union is itself a secret organization, which avoids responsibility before the law by refusing to be incorporated; and, as we have all seen lately, the strike is often resorted to for reasons not made public, or at least not made public till after the strike has 


\section{Shortcomings of American Education}

taken place. To use in industrial conflict this weapon forged in secret is to exhibit an utter lack of faith in the very best means of remedy for industrial wrongs, namely, publicity. When the capitalists or the middlemen who resist a strike do so without publishing their reasons, the demonstration of lack of faith in publicity is complete. Yet publicity is the great security for democracy; the best weapon against political, social, industrial, or commercial wrongdoing, and, in the long run, the most trustworthy means of political and social progress. To distrust publicity is to distrust the intelligence and ethical sense of the people, the only safe foundations for free institutions. It seems as if democratic schools ought to 
have brought forward in a hundred years generations of workmen and employers that would hold firmly in all their affairs to the fundamental, moral ideas on which the republic rests; but this success popular education has not achieved. The industrial wars which so seriously diminish the productiveness and prosperity of the country are evidences that the common schools have not grappled successfully with the tremendous problem put before them; and this remark applies just as much to the employers as to the employed. It is to be said for the labor-unions that they heartily believe themselves to be contending at present sacrifice for the future good of the working class - even of the non-union men, whose 
40 Shortcomings of American Education

independent conduct of their own affairs the unions now condemn. And the same faith is to be discerned in the employers who combine to resist a strike. They, too, believe that at present sacrifice they are contending for the future good of their class and of the country. When I use these industrial conflicts to illustrate the inadequacy of American schools, I am impugning not the motives of the combatants, but their intelligence-an intelligence which such education as the country supplied has left seriously defective. In these days such conflicts, if they have reasonable grounds, are ultimately settled by reason; yet the parties to them are often stupid enough to try for months to settle them 
by force-that is, by inflicting pecuniary losses and physical and moral injuries, and creating widespread confusion and alarm. Verily, as Franklin said: "Experience keeps a dear school: but fools will learn in no other, and scarce in that." It is clear that American common schools have not succeeded in preventing that sort of fool from abounding.

In certain parts of American social life in which the ideal standards have been held high there has sometimes come lamentable failure. For example, there is one element of American freedom which many of our people have valued very highly, but which has produced results of a character peculiarly disappointing. I refer to that freedom 
42 Shortcomings of American Education in social relations between the sexes which is supposed to result in marriages based on love and natural affinity, rather than on family interests, pecuniary negotiations, or considerations of social advancement. Here is a region in which one would think that the happiest results should have flowed from freedom combined with diffused education; and certainly, when American marriages are happy, they are very happy. But there are formidable facts on the other side of the account. The statistics of American marriage and divorce seem to show a frightful proportion of unhappy marriages, of sterile marriages, and of marriages which result in a small number of children; while to match the statistics 
The Spoils or Patronage System 43

of divorce among people of American descent in some of our states one has to go to Moslem communities. In this all-important department of American life it is clear that the free schools have not prevented the development of formidable evils. Now, home and school react on each other. Whatever impairs family relations increases the difficulties of schools and colleges; whatever raises the school improves family life. The enlightening and conservative influence of the school in social matters is to-day all the more needed because the control formerly exercised by the church has been loosened.

The spoils or patronage system in the civil service of the United States illustrates in a striking way the inade- 
44 Shortcomings of American Education

quacy of the training supplied by the public schools. This mortifying display of popular obtuseness reached its climax at about the end of the second third of the nineteenth century, and has since been very slowly declining. It was a real fooling of the people by catchwords and plausibilities, a sacrifice of the large public interest to small private interests, and a widespread application in a republic of the methods habitually used by aristocracies to corrupt and rule the plebeians, including one of the most demoralizing of those methods, the establishment of numerous sinecure offices. To be sure some original follies were added, such as a low scale of salaries in the higher offices and a high scale in the lower, and 
Spoils System Fools the People 45

a rapid rotation in office which gave the long-suffering public a succession of inexperienced and therefore incompetent servants. Many people have supposed that the introduction, development, and tenacity of the patronage system in the United States were evidences of moral perversion in the mass of the people. Doubtless there has often been moral obliquity in the patrons and sometimes in the patronized; but it seems to me that in the great mass of the people it has been chiefly lack of perceiving and reasoning power which has caused them to submit to, or even encourage, the patronage system. They have neither seen straight nor reasoned clearly about its undemocratic, corrupting, and inefficient qual- 
46 Shortcomings of American Education

ity. They have not understood how demoralizing to youth is the hope of getting on in the world by the unearned favor of powerful persons. Now a popular education which leaves many millions of the people in this mental condition on a subject which touches nearly their daily welfare and the safety of free institutions is surely inadequate to the needs of the republic.

Lastly, the final test of the value of the education given to an individual or to a nation is continuous mental growth. The human body has a continuous development up to the age of twenty-five or thereabouts, should then have a long period of level health and strength, and after sixty may be expected to decline. There should be no 
corresponding stages in mental development. The growth of a man's mental and spiritual powers should be continuous through life, and his last years should be his best. It is this continuous mental development which proves better than anything else that the education received in youth was effective, and that the subsequent mode of life has been all along wholesome and improving. If we include in this growth the development of what is called character, this continuous enlargement and improvement is the supreme human felicity. Now there are two common obstacles to the attainment of this felicity-the first is the untimely arrest of education in youth; the second is the dulling and contracting effect of 
48 Shortcomings of American Education

many methods of earning the livelihood. Any comprehensive survey of the social and industrial conditions of the American people will bring an open-minded inquirer to the conclusion that these two obstacles to the continuous development of the human individual are both formidable to-day. For millions of American children systematic education stops far too soon; and for millions of adults the mode of earning the livelihood affords so little mental training, and becomes so automatic, that mental growth is seriously hindered, if not arrested. I find here a strong argument for the expenditure of more public money on the education of the children, that they may be held longer in the schools with greater profit and 
Importance of a Taste for Reading 49 greater enjoyment, and therefore have a better chance for continuous growth afterward; and, secondly, I find in these considerations a strong argument for a moderate number of hours of daily labor in those occupations which have little variety and call for little exercise of an intelligent judgment. These unfortunate conditions may be best resisted in the individual case, or in a million cases, by the steady gratification of a sound taste for reading; and the implanting of this taste in every child before it leaves school is therefore a matter of supreme importance. How else is the child who leaves school at twelve, fourteen, or sixteen years of age to feed its mind? How else is the adult to nourish and expand his mental 
50 Shortcomings of American Education powers, if he must spend ten hours a day in tending a machine, or in making day after day and year after year in his regular occupation the same observations through eye and ear, and doing the same things with hand or finger in the same order or with incessant repetition? In such cases-and they occur by millions-it is in reading and in the play of the domestic affections and the social interests that lie all the possibilities of mental and spiritual growth. Shall we not all agree that from this point of view the American schools have thus far been much less serviceable than they ought to have been, or, at least, than we want them to be?

These illustrations will suffice to 
Disappointments in Other Fields $5 \mathbf{I}$

convince us that the results of American education have hitherto fallen far short of the hopes and expectations of its founders and advocates, and that it has great tasks before it if it is to promote effectively public righteousness and the general welfare and happiness. But these great tasks will involve the greater expenditures I am pleading for.

To console us teachers, however, I hasten to say that it is not in national education alone that we have suffered heavy disappointments. Our predecessors of a century ago expected that when churches were freed from all connection with the state, and were supported by the voluntary contributions of their several bodies of adherents, everybody would attach himself to the 
52 Shortcomings of American Education

church of his choice; and so religious teachers would have access to the entire population. We have learned by experience that under the voluntary system a large portion of the population never - goes into a church. We thought that universal suffrage would be in itself a great educational influence-as indeed it is. We have learned that it is not a panacea for all social ills. The Abolitionists of 1860 and the Republicans of I 865 thought that the Negro would take care of himself if only he ceased to be a slave; but after Negro experience of a comparatively large degree of personal liberty for a whole generation the nation still has a fearful Negro problem on its hands; and millions of our countrymen maintain that no white man should 


\section{Cities Better Governed Elsewhere 53}

invite a black man, however agreeable and interesting, to eat with him, and imagine that political equality necessarily carries with it social intercourse on terms of equality, whereas universal experience is entirely to the contrary. The average American thinks to-day that free institutions must necessarily produce a more satisfactory public service than can be procured under monarchies or empires; but the ancient city of Rome, the capital of a monarchy, has to-day a much lower death-rate than any large American city. The city government of Glasgow can not only provide water, highways, bridges, sewers, street-cleaning, schools, fire departments, parks, public libraries, and art galleries for its 800,000 people, 


\section{Shortcomings of American Education}

but can also supply gas, electricity, wash-houses, markets, lodging-houses, homes for widows or widowers having young children, and street railways; and all these good things, in addition to what New Haven or Boston does, Glasgow does at very low rates to the public, and with profits to the city itself. For a small-scale comparison of the same sort, take the little English colony of Bermuda, with a resident population of 6,000 whites and 10,000 blacks. There is mail delivery of letters and parcels at every house on that island twice a day; and the books of the colony's library in Hamilton are carried by the mail free to and from any house on the island. I know no American rural community which enjoys the like privi- 
Public Service Better Elsewhere 55

leges. The fact is that a good many public services are performed by governments which we should not describe as free, better than they are performed by the corresponding departments of our own government; or, in other words, free institutions have not produced in three generations better public service in all respects than other institutions, although they are in themselves more educative than any other. Herein is a grave disappointment for democrats by inheritance and conviction. This is not saying that there is any people in the world more fortunate on the whole, or happier on the whole, than the American people. Thus, the municipal government of Philadelphia is very inferior to the government of Berlin; but for the 
56 Shortcomings of American Education

average working and thinking man Philadelphia is a happier place to live in than Berlin. The government of Boston is, as a government, inferior to that of Glasgow; yet Boston is, on the whole, a vastly better place to live in than Glasgow. The other effects of social and political freedom make the northern United States the most prosperous community in the world, in spite of the fact that the efficiency and moral tone of the public service is in some departments better in less free countries than in our own. Our people are too impatient for peerless fruitage from the slow-growing tree of liberty; we all expect sudden miracles of material and moral welfare-we get only a slow development and a halting progress. It 
American Education a Novel Problem 57 is not then in regard to public education alone that democratic hopes and expectations have been seriously disappointed.

Let us now consider briefly some of the unprecedented difficulties which American education has not yet been able to overcome.

It is a huge and novel problem with which education in our country has been struggling from the first starting of schools and colleges in the American wilderness; and the problem has all the time become larger, and still persists decade after decade in proving novel. We are trying to prepare all American boys and girls for a life of unprecedented freedom-freedom of thought and 
58 Shortcomings of American Education

speech; freedom to travel, to change the place of abode, and to change the occupation; freedom to enter into any sort of public or secret association or union; freedom from everything resembling castes or insurmountable social or political barriers. No other country of the civilized world-not even the Australasian Confederation-offers its children so complete an exemption from the social and industrial limitations which in the past have hedged the way. of the tradesman, the mechanic, and the peasant. Moreover, in no other civilized country of the world is there such an absence of effective police supervision as in the United States. One must say that there is none in country districts, and that in urban districts it 


\section{The Law Has No Strong Arm 59}

is ordinarily ineffective. Even wellknown members of the criminal class are under no effectual control, and by merely changing from time to time their field of operations often succeed in preying on the community for years. The law has no strong arm. On the continent of Europe the army seizes on every able-bodied youth, and subjects him during from one to three years to a severe discipline which does some good to the least civilized of the conscripts. There is nothing of that kind in the United States. The task of American schools and colleges has, indeed, been a novel one from the start; for they must not only train the intelligence of every pupil, but implant moral restraints and ideal standards, which 
60 Shortcomings of American Education

will help him through the perils of an unexampled liberty.

It is then for a society of unprecedented mobility and unprecedented freedom of action that the American schools and colleges are endeavoring to prepare their pupils. Good results of this extreme mobility and freedom, as well as bad, are evident on every side. The son of a shiftless, roving, pioneer farmer becomes through extraordinary gifts of body and soul President of the United States; an illegitimate boy in an obscure country town becomes a preacher, teacher, and author of distinction; innumerable men of humble origin; brought up in narrow conditions, become leaders in industry, trade, finance, and the professions. The population is 
Diversity of American Families 6r

characterized by restless ambition, the spirit of adventure, the love of things new, and irrepressible personal initiative. It is for a community different from any that ever before existed in the world that the American schools and colleges are trying to educate all the children.

Again, American schools and colleges have a task without precedent, because of the extraordinarily varied nature of the families to which their pupils belong. It is impossible for a day school to replace family culture, or to make good the lack of a sound intellectual and spiritual influence at home. In all our cities, even the oldest, the schools have to deal with families of various races, religions, and social histories. Thus, Boston in the eighteenth 
62 Shortcomings of American Education

century had a very homogeneous population; at the beginning of the twentieth it has a population of extraordinary diversity. The country is assimilating people from all over Europe; and it is the American school which effects the greater part of the assimilation. No other schools and colleges in the world have such a task. It is this difficulty which so retards the success of the new efforts to teach the English language and literature in the public schools. A day-school can hardly overcome the effects of rude speech, or foreign speech, at home. If the multifarious people who emigrate to America had had experience of public liberty, the task would be easier; but the greater part of them have had experience of oppression, 
Rapid Changes in American Life $6_{3}$

of economic defeat, or of impenetrable social hedges. No wonder that American schools and colleges have staggered under this almost unsupportable burden.

Again, our schools and colleges have been trying to prepare their pupils for a subsequent life out in a world which has itself been shifting and changing with an unprecedented rapidity. The life for which the American schools should now prepare their pupils is an utterly different life from that for which the schools were preparing the children forty years ago-or even twenty years ago. All the scenes have shifted within a single generation. The younger people in this hall can hardly imagine the elementary condition of the Ameri- 
64 Shortcomings of American Education

can cities only two generations ago. You will permit me to take Boston as an illustration, because it was and is an old, rich, well-settled place with which I have been familiar. The little city had no water-supply, no sewers, no gas, no street-railways, no well-paved streets, no paid fire department, hardly any police (and that not uniformed), no public library, no electricity, no screw steamers, and no park except the Common; and foreigners were so few and strange that a serious riot took place in Broad Street when my father was mayor which was entirely due to racial and religious prejudices between the Protestant Americans and the Catholic Irish. It is obvious that nothing resembling the complex, intense, 
and stimulating city life of to-day could have existed in such a community. The schools and colleges have hardly been able to keep pace with the astonishingly rapid changes in the industrial and social conditions of the population. Indeed, American school committees have often proved themselves incompetent to provide beforehand against the plainly visible shifting of population from the heart of a city to its suburbs, or against the steady inrush from the country to the city. We have made great advances in regard to preventive medicine and sanitation, and these improvements have been shared by the schools; yet new evils are constantly arising in our urban communities, and the beneficent discoveries in medicine 
66 Shortcomings of American Education

and surgery hardly keep pace with the new evils which result from the congestion of the population. Thus the schools struggle with the problem of contagious diseases among their pupils, and slowly become less troublesome as propagating houses for mumps, measles, scarlet fever, smallpox, and diphtheria; but to offset this gradual improvement new centres or sources of infection are constantly created, such as crowded street cars, populous tenement-houses, unventilated public halls, thronged eating-houses and workrooms, filthy paper money, and the fouled watersupply, celery bed, oyster-bed, or dairy.

The whole world has been made over since 1850 , and with many new powers for good there have come in 
The World Made Over Since 185067 many new powers for evil. We have to-day telephones, telegraphs, submarine cables, the great ocean steamship, sewing machines, mowers and reapers, street-railways, subways, turbines, electric motors and lights, and steamengines innumerable; and from all these things immeasurable benefits have flowed; but they have given us also huge factories, masses of operatives who spend their lives tending imperative machines, or making only some small fraction of a complex product, overcrowded tenements, vast cities, formidable combinations of capital on the one hand and of laborers on the other, the rifle which kills at a mile and a half, the Lyddite shell, and the battle-ship. As I said a year ago at the 
68 Shortcomings of American Education celebration of the two hundreth anniversary of Yale University, "industrial, agricultural, and social conditions have so changed that not a man or woman in our broad country now works in the same way or to the same results as men and women worked in I70I-not a soldier or a sailor fights to-day in the least as soldiers and sailors fought when Yale was born. The most vital change of all is a new spirit animating the corporeal mass of civilized society, a spirit pervasive, and aggressive-the all-modifying spirit of Christian democracy." The American schools and colleges have had to readjust themselves incessantly to these sweeping changes in the condition of society; and it is not to be wondered at if they have 
Schools Have Been Left Behind 69

often failed to keep pace with the rapid steps of this wonderful transformation. It must be confessed that the schools have not changed and improved so much as the means of transportation, or of manufacturing, or of lighting and heating, or of farming, or of mining. The schools have, of course, improved; but they have not kept pace with the industrial and social development of the past fifty years; not enough money has been expended for them, and so they are still using obsolete plants and methods.

One of the principal changes in American society within the last fifty years has had a profound effect on schools and colleges, namely, the transfer of the great majority of the popula- 
70 Shortcomings of American Education

tion from the country to the city. Children brought up in the country get a deal of invaluable training from their rural surroundings. They roam the fields and wade in the waters, observe plant and animal life, use and take care of domestic animals, help their fathers and mothers in the work of the house and the farm, and thereby get invaluable training-first in observation, secondly in attention to the task in hand, and thirdly, in good judgment when at work-the judgment which prevents waste of strength, and distinguishes between the essential or immediately necessary in productive labor, and the unessential and deferable. A roaming country child, brought up on a farm, learns unconsciously 


\section{The Lost Training of Country Life $7 \mathrm{I}$}

from nature much that it is almost impossible to impart to a city child. In city schools we have been for twenty years past laboriously trying to provide substitutes for this natural training in country life. The recent natural history study from specimens used indoors, the manual training in carpentry, forging, filing, and turning, the garden-plots and roof-gardens, the vacation schools, and the excursions to parks and museums, are all sincere efforts to replace for urban children the lost training of eye and hand which country life supplied. It is impossible to exaggerate the importance of these substitutes; but after all they are inferior to the spontaneous, unenforced results of living in contact with nature, and of taking 
72 Shortcomings of American Education

part with mother and father in the productive labors of a farm, a market garden, a hennery, or a dairy. What children acquire in the spontaneous, intense, self-directed use of their faculties is always more valuable than the results of a less eager though more prolonged attention to enforced tasks.

These considerations may be accepted as reasonable explanations of the shortcomings of American education. They do not alter the facts that the disappointments of its advocates and friends have been many and deep, and that immense difficulties beset its path.

What should be the effect on our minds to-day of these disappointments and of these unsurmounted difficulties? Surely a new and hearty resolution to 
One Wisdom for Family and Nation 73

do what we can to make the schools better and more effective to all righteous ends. But this greater effectiveness unquestionably means greater costliness. The heavier the disappointments of the past, and the graver the present difficulties, the firmer should be our resolvesfor the future, and the more urgent our appeals to the governors and leaders of the people to appropriate more money to the free schools. Could anybody imagine it to be unreasonable to spend for the mental and moral training of a child as much as is spent on his food? If that equality in expenditure could be established all over the Union, there would result a prodigious improvement in the public schools. I have already pointed out that well-to-do families 
74 Shortcomings of American Education spend a great deal more on the education of their children than on their food and lodging, and this is undoubtedly family wisdom, whether it be viewed from the material or the spiritual side. In all probability, what is wise for a well-to-do family would be wise for the nation as a whole. 


\section{More Money for the Public Schools, Because of the Gains Made in American Education}

[An address before the New Hampshire State Teachers' Association on October 18, 1902.] 



\section{THE GAINS MADE IN EDU- CATION}

Testerday, at New Haven, in advocating larger expenditure on the public schools, I dealt with some of the many failures and disappointments that our people have suffered in regard to the results of the common-school system. To-day . I propose to point out the substantial gains which the American schools and colleges have made during the past thirty years-gains which have all involved increased expenditure on education-and to draw from these costly 


\section{The Gains Made in Education}

gains, which the people have approved, encouragement for still larger expenditures in the future.

The first gain I wish to mention is the kindergarten, which was tardily introduced into our country, and is not yet widely adopted as part of the public school system. It is a comparatively expensive addition to a school system; because the proportion of pupils to a teacher is small in the kindergarten, each child receiving more of the personal attention of the teacher than is ordinarily given in a primary or grammar school. The best effects of the kindergarten have been produced by its insistence on invariable gentleness, on interesting the child, and on avoiding long 
Contributions of the Kindergarten 79

periods of attention to one subject. Gentleness takes more time and patience than peremptoriness or violence, and is therefore more costly; to interest children requires more effort than to drive them to the performance of set tasks, and is therefore more costly. As I look back on the schools of which I have had personal observation, I perceive that on the whole the stupidest thing in their arrangements was the long period of attention to one subject. Nothing can be more unnatural to a young child than attention to the same subject for half an hour;

- a minute is a much more natural period than half an hour, and a healthier one. Even for students of university age, or for such an audience as this, it is doubt- 
80 The Gains Made in Education

ful whether fifty-five minutes be not an impossible period for really sustained attention. There are few adult students whose attention does not wander from the lecturer's words within half an hour. About this matter schools and colleges of every grade have learned much from the kindergarten, that costly addition to the American public school system. They have also learned from it much about the importance of dealing with the individual child, rather than with large groups of children. In this respect kindergarten methods and the methods of the conference or seminary at the university closely resemble each other. Again, as the university professor is ordinarily provided with a very serviceable young assistant, who is an intelli- 
gent and well-trained aspirant to the university career, working like an apprentice for low pay, so the kindergartner has her helpful assistant, who is hoping to learn the business -an arrangement highly suggestive for all school grades. The kindergarten also sets an excellent example to all schools in making it part of the teacher's function to know something personally of the families from which her pupils come. We shall never get the education of children between six and fourteen right till this kindergarten method runs through the primary and grammar schools, or, in other words, through the first eight grades. These lessons from the kindergarten have been taught by the estab- 
82 The Gains Made in Education

lishment of a few kindergartens in comparatively few communities; but they indicate perfectly clearly what great profit to the children a moderate addition to school expenditure can yield.

In the selection of the studies of the first eight school years out of the twelve, there has been substantial improvement within thirty years. Thus there are more observation studies on the programme, less arithmetic, and a little more geography; less spelling and grammar, and more literature; wiser teaching of geography as a natural-history subject, and not an account of obsolete or trivial political divisions, and a list of names of bays, capes, rivers, mountains and capitals ; a better teaching of history 
as a story of discoveries, industries, commerce, peoples, and institutions, and not of battles and dynasties. These improvements in the selection of studies have all involved additional cost. Arithmetic is a very cheap subject to teach; so are spelling and the oldfashioned geography. As to teaching history in the old-fashioned way, anybody could do that who could hear a lesson recited. To teach nature studies, geometry, literature, physiography, and the modern sort of history requires well-informed and skilful teachers, and these cost more than the lesson-hearers did. But how slowly these improvements make their way, and how inevitably the sins of the fathers are visited on the children to the third and fourth 
84 The Gains Made in Education

generation! Bad traditions in education die hard. At this moment some parents in whom I am interested cannot prevent the time and strength of their boy of nine from being wasted on the study of arithmetic at his first school. He must go to a school and not be taught alone; that school thinks it must meet the requirements for admission to the neighbouring school for older boys; and there the requirements for admission in arithmetic are somewhat strenuous, although that school prepares most of its boys for Harvard College, and there is no examination in arithmetic for admission to Harvard. One-tenth of that little boy's school time given to arithmetic would be too much; but he 
The Aims of the Primary School 85

is giving about one-quarter, and his parents are helpless. The other day that same boy was behaving unsuitably, and, after patient remonstrance, his mother told him that he must either do as she wished or leave the room. $\mathrm{He}$ reflected for a moment, and then remarked- "Yes, that's fair," and amended his behavior. That judicial comment affords, to my thinking, greater promise of subsequent usefulness in the outer world as it is than any amount of accurate figuring. The true aims in a primary school are to store the mind with fair pictures, implant ideals, cultivate the habit of intense though brief attention, and train the sense of justice. Let us, however, take courage from 
86 The Gains Made in Education

the gains already made in regard to the selection of studies in the first eight grades, and press toward further gains of the same sort, at additional cost. Another urgent need of the first eight grades is greater attention to the individual, which means fewer pupils to a teacher, and minuter classification according to quality and capacity; but these improvements will all cost money.

Important improvements in the programmes of secondary schools-the schools which claim our children from fourteen to eighteen years of age-have also taken place. Thus, fewer subjects are now required of the individual pupil than formerly, although more subjects are taught in the schools. This is a great change for the better; because the atten- 


\section{The Fateful Forking of the Ways 87}

tion of the pupil can be more concentrated on kindred subjects, and one or two subjects may be carried beyond the elements. You perceive, however, that this improvement must have involved larger expenditure. To carry it further will, of course, involve larger expenditure still.

Again, it is a great improvement in secondary education that more and more the important decision concerning the termination of education can be postponed. It makes an incalculable difference in the future career of a boy or girl, whether his or her education is to stop at fourteen, at eighteen, at twenty-one, or at twenty-five, and the longer that vital decision can be postponed the better. When our boys had 
88 The Gains Made in Education

to decide at fourteen between the high school which could not possibly get them into college or scientific school, and the Latin school which could; or between a classical course, which would permit them to enter higher institutions of education, and an English course, or a commercial course, which would not, the most important decision in the young life of the individual, most important both for himself and for his family, was made far too early. The postponement of the forking of the ways in secondary schools, whether public, private, or endowed, and the gradual introduction of the elective system into such schools are both valuable improvements in the direction I have indicated. You cannot fail to 
observe, however, that this postponement of the forking is largely a question of expense. In earlier days the Latin school cost much more than the English high school; and to-day the classical course costs much more than the English or the commercial course. If, then, the forking be postponed till the sixteenth or seventeenth year, it follows that a more costly education is given to all children from the fourteenth up to the sixteenth or seventeenth year.

It has been my professional duty for more than thirty years to watch the gradual improvement of the education given in the public high schools; and there is no more striking phenomenon in the whole course of American educa- 
90 The Gains Made in Education

tion than that improvement. I doubt if there be any educational development which has more clearly commended itself to the American people as a whole. The increased resort to high schools since $\mathrm{r} 885$ is convincing evidence that the improved opportunities are understood and appreciated. Are we not justified in drawing from this approved increased cost encouragement for still further increase of cost, not only in the secondary schools, but all along the line? But again we are forced to notice that these improvements penetrate American schools and colleges as a whole only very slowly. The past year was the first year of a promising experiment in Boston on election of studies in the public high schools-an experiment 
all the more promising because made with so much power in the hands of head-masters as to insure a variety of experimentation.

The continuous creation of new secondary schools for boys, placed agreeably in the country, has been a noticeable phenomenon during the past thirty years. The old New England academies were in part killed, and in part stunted, by the establishment of the public high schools sixty years ago, although the strongest of them-like Exeter and Andover-survived. The revival of the country boarding-school is due in part to denominational zeal. The Episcopalians led the way in this revival, the Presbyterians and Unitarians following after; some of the old 
92 The Gains Made in Education

Baptist and Methodist seminaries have been preserved; and a few of the old denominational academies have been rebuilt and reëndowed. Other motives, however, have impelled toward the same end. The growth of the cities and large towns has made it difficult for parents to bring up boys in the cities under healthful conditions, and the luxury of the home life among some rich people has proved prejudicial to their children. The parents themselves have seen this, and have adopted the European remedy of sending the children away from home. Now all these schools are much more costly than the dayschools which are open to the same boys at their parents' places of residence. Their creation shows that large 


\section{The Endowed Schools Are Leaders 93}

numbers of American families are prepared to spend money freely on the education of their children. The creation or preservation of this considerable group of endowed secondary schools is a fortunate circumstance for the entire public; for these schools are on the whole more progressive in their methods of instruction and discipline than the public schools. Their resources generally permit them to employ more teachers in proportion to the number of pupils than the public schools are permitted to employ; they can hold their pupils to their tasks better than the public schools, because they have them under control all the time; and they can take better physical care of their pupils than is possible at schools situated in 
94 The Gains Made in Education

closely built cities. Their methods and expenditures, therefore, point the way of progress for the primary and secondary schools which are supported by taxation, allowance being made for the difference between boarding-schools and day-schools. It is interesting to see that the same social conditions which determine the maintenance of good boarding-schools in England and on the Continent are creating similar schools in the United States. They are useful to families that live a large part of the year in the country, where no good day- . school is to be found, and to families which travel or live in foreign parts, and wish to have their children educated in this country. If many well-to-do American families are to pass consider- 


\section{Improvement in School Buildings 95}

able portions of their lives in Cuba, Porto Rico, Hawaii, and the Philippines, as many British families do in British dependencies, there will result an increasing demand for good country schools in salubrious parts of the United States. Such schools will need to combine as far as possible the good influences of home, school and church. They are sure to be costly.

Within twenty years past there has been throughout the country a striking improvement in school buildings, the expenditure for this purpose having been in many communities very generous. These new buildings are much better heated and ventilated than schoolhouses used to be. They are also kept rather cleaner than schoolhouses were formerly, 


\section{The Gains Made in Education}

although there have been within recent years some extraordinary revelations concerning the infrequency with which schoolrooms are thoroughly cleaned. In general, cleanliness is very imperfectly enforced in schoolhouses, whether in the city or in the country. The standard of cleanliness in hospitals and infirmaries is much higher than it is in schools, which, of course, should not be - the hospital being only a palliative or curative for existing evils; the school being a positive, productive, and constructive power for good. Architects should be just as careful about their mouldings and corners in a school building as in a hospital; and dust should be as scrupulously removed from one class of buildings as from 
the other. In the light of recent discoveries concerning germs and dust, it is strange that in most of the heating apparatus used in our houses, schoolhouses, and churches, convenient access to the air-ducts (cold and hot) is very seldom thought of. We let the interiors of our cold-air boxes and our hot-air flues go for years without cleaning, because they are apt to be so built in and covered up that they are not accessible to brushes and sponges. In spite of these defects, however, the increased expenditure on school buildings and the furniture and apparatus they contain is a very encouraging sign that the public is prepared for still further expenditure on education.

The improvement of heating and 
98 The Gains Made in Education ventilating apparatus in schoolhouses has, however, brought a new charge on the teacher. Such apparatus will seldom run itself. Its defects have to be constantly watched and reported on, and to do this intelligently the teacher needs to know something about the construction of the apparatus itself and its mode of action. In the southern parts of our country the heating and ventilating apparatus is much less important than in the northern. In the South very simple means of heating can be used, and the windows will serve for ventilation. The healthiest and most vigorous set of children that I ever saw in a school were the pupils of a Scotch school, called the "Dollar Institution," in the town of Dollar. 
The schoolhouse had the simplest means of heating and no means of ventilation. The wholesome method in use was to turn everybody out of the building for five minutes at the end of each hour, all the windows being thrown wide open; teachers and pupils alike went out of doors for these five minutes. It was snowing hard at the time of my visit; but that made no difference. This successful method, however, requires something which most of our city schools lack-namely, an open space about the schoolhouse large enough for hundreds of pupils to walk and run about in.

The cost of urban public school systems has been materially increased during the last twenty years by the 


\section{roo The Gains Made in Education}

institution of four new kinds of schoolthe manual training school, the mechanic arts high school, the evening school and the vacation school. All these branches of the public school organization were introduced into our country by private beneficence, and have only gradually been adopted into public school systems. The manual training school, the mechanic arts high school and the vacation school are undoubtedly permanent institutions of public education. Evening schools may or may not prove permanent. At present they remedy deficiencies of education in young people who are of foreign birth or who have too early gone to work to support themselves or their parents. If public education were universal and thor- 


\section{Four New Kinds of School ror}

oughly effective the evening school would not be so much needed. Its duration as an institution will therefore depend on the rate at which public school systems improve in efficiency. All these new branches of public instruction are somewhat expensive additions to the ordinary day schools - the mechanic arts high school being particularly expensive, as well as very useful. The utility of manual training for city children has been thoroughly demonstrated, and there can be no doubt that this somewhat costly form of instruction will be maintained and developed. The acceptance of these four new kinds of school as schools properly to be supported by taxation illustrates strikingly the readiness of 
102 The Gains Made in Education

the American population to undertake new burdens for the education of its youth.

Great improvement in the quality of the teachers in American schools has taken place within the last thirty years. The improvement is due to several causes. In the first place, the education of teachers on the average has greatly improved. The higher education of women has benefited the schools very much, for many women educated in colleges have become school-teachers. The recent elevation of normal schools is having a like beneficial influence on the primary and secondary schools. These institutions were for many years after their first establishment through the influence of Horace Mann little 
Lifting the Normal Schools 103

more than high schools of moderate excellence; they were better than the poorest high schools, but not so good as the best; their requirements for admission were low, and they offered a short cut to the business of teaching. In Massachusetts, where normal schools began, a great gain has been effected by requiring for admission to the normal schools the previous accomplishment of a high-school course of study. This advance is so recent that its full effects are by no means worked out. The coming decade should amply demonstrate them. Secondly, the methods of selecting and appointing teachers are much better than they used to be. The examinations for admission to city school systems are more adequate than 
Io4 The Gains Made in Education

they formerly were, and positions are filled, to a greater extent than formerly, by sensible, competitive methods, based on proved merit. There are, of course, large remnants of patronage methods; but they are slowly being condemned as injurious to the schools, and discreditable to all who use or profit by them. On the whole, the tenure of school-teachers is longer and juster than it used to be. Still another encouraging feature is the steady approach toward an adequate pension system. No large body of teachers can possibly be kept in the most efficient condition without a pension system; and since a judicious pension system is by no means costly, it may be hoped that before long this method of promoting the efficiency of 
public and endowed schools will be generally adopted. The present-not uncommon-method of keeping enfeebled or aged teachers at work on their full salaries wastes money and injures the children. Justice, mercy, and a reasonable frugality all combine to urge the creation of a pension system for teachers. That soldiers, sailors, policemen and firemen should have pensions for disability or long service, and that disabled teachers should not, is a preposterous inversion of the true order. Retiring allowances are rapidly being introduced into the better universities of the country, with the best effects on university services; and it is high time that the public school systems procured analogous advantages. Even commer- 
ro6 The Gains Made in Education

cial companies, like railroads, find it advantageous to establish pension systems. Reviewing these changes in the education, modes of appointment, and tenure of school-teachers, it is obvious that they all tend to make the teachers more highly trained for their work, and more permanent in service. That means, of course, higher salaries, and a heavier total charge for salaries in the public schools. No change in the condition of the public schools can be more important than this, and what has already been done in this direction is evidence that the community will hereafter go further in the same direction. Within twenty years there has been an increasing employment of educational experts in the surpervis- 
Functions of School Committees 107

ing and executive functions of urban school systems. The former method of entrusting executive functions to small subcommittees of a large school committee is passing away; and we may reasonably hope that this method will soon be extinct. It has long outlived its usefulness. The school committee of a large city should be a small body of much-trusted citizens, serving without pay, whose duties should be to determine the general policy of the system, and to select the educational experts who perform all supervising and executive functions. This transformation has been effected in a few American cities with the best results, and is to be recommended wherever the size of the system is 
ro8 The Gains Made in Education

sufficient to warrant the employment of even a single expert superintendent and a single business manager. The new officers cost more than the old-fashioned sub-committees that served without pay, but no new expense for public education has so completely justified itself as this in both city and country.

The remarkable increase which has taken place within the past fifteen years in the proportion of American children who attend secondary schools is a great educational gain for the whole country. The causes of this sudden increase are probably numerous, and different in different communities; at any rate, they are complex, and one cannot feel sure what they are. Probably parents realize more and 
Increased Use of High Schools rog

more that the more prolonged the education of a child, the better his or her chance will be in the competition to which every newcomer is exposed in the world of industry and commerce. The opening of many new employments to women has had some effect to increase the resort to high schools, just as it has surely increased the resort of women to colleges. Child labor in factories is a bar to school attendance; but no such objection applies to the new occupations for women in the commercial world, since these occupations are hardly accessible to women before eighteen or twenty years of age. It is true that the attendance at the high school diminishes too rapidly in the successive years of the course; but 
ro The Gains Made in Education

every year gained by the pupil is well worth having. Indeed, there are competent observers who think it would be wise to blur as much as possible the line between the grammar schools and the high school, by carrying studies now confined to the high school down into the grammar schools, and postponing as much as possible the segregation of the more advanced pupils in a separate building. By these changes the grammar-school course could be much improved; and a larger body of pupils could be held under instruction after their fourteenth or fifteenth year. Another suggestion looking to the same end is the six-years' highschool course. You have doubtless observed that the change now under 
consideration has involved substantial increase in the cost of the schools supported by taxation, and that this increase has been borne with satisfaction by the communities concerned.

The successes obtained in the higher education of the country during the past thirty years admirably illustrate the fact that much more money has been spent on education by the generation now in activity than by any of its predecessors, and spent with entire satisfaction. The greatest educational success of the last thirty years is the complete adoption of the elective system

- in a few institutions, and its partial and progressive introduction in almost all. Yet the elective system is indefinitely more costly than the prescribed. 


\section{2 The Gains Made in Education}

It should be remembered that it is a system, and not an unorganized chaos, or a distracting bazaar; it has made real scholarship possible to thousands of young Americans by the time they are twenty-two years of age; it has raised very much the standard of labor for both teachers and taught in our colleges and universities; and it has made it possible for thousands of American students to win that delight in study which accompanies the sense of mastery or of clear achievement. It has also improved immeasurably the relations between professors and students, mollified college discipline, and greatly ameliorated the manners and customs of college students. As yet it has by no means wrought out all the good 
it can do; but it is firmly established throughout the country, and thus far it has followed in other institutions the same stages of development that it followed at Harvard. Indeed, this development follows everywhere the same lines; so that one may prophesy in any institution, where it is partially. developed, what the next step will be. It is an inevitable result of the immense increase of human knowledge in the nineteenth century. Accompanying this great administrative success is another improvement in the higher education which is of the utmost value. The standard of attainment for professors has been very much raised during the past thirty years; and even for a subordinate position in a college faculty, the 
II The Gains Made in Education

standard is now immeasurably higher than it was when I was appointed a tutor in Harvard College in 1854 . This change means that the university teacher now undergoes a longer and more thorough preparation for his function: and accordingly the university teacher must be recompensed for this longer training by a higher salary.

In no department of education has greater improvement been made during the past generation than in professional education. The whole provision for training young men for the new scientific professions has been created in this country during the last fifty years; and America's success in the scientific industries is evidence that the new schools of science and technology have 
Improved Professional Training I I5

done good work. It is to be remarked that an important part of the training for the scientific professions is laboratory work - the most expensive form of teaching now known; for it is teaching addressed to the individual student by experts. The changes, however, in education for the old professions of divinity, law, and medicine are quite as striking as the new creations for applied science. If I were asked to say in what department of Harvard University the educational change had been greatest since 1870 , I should answer the Medical School. There, and in many other medical schools of the United States, the whole method of instruction has been changed root and branch; and the raw material of the 


\section{I16 The Gains Made in Education}

school-the incoming students-has changed to an extraordinary degree within the same period. In I870 anybody, no matter how ignorant, could enter any medical school in the country. At the Harvard Medical School the examination for graduation was limited to five minutes in each of nine subjects; and to get a degree it was only necessary to pass the examination in five subjects out of the nine. This past academic year the Harvard Medical School required a degree in arts or science for admission to the School, and for many years past every graduate has been required to pass a thorough examination in every subject of instruction embraced in his course before he could receive his diploma. Nine-tenths of 
Training for Medicine and Law II7

the instruction now given in a good medical school is instruction given to individuals by highly trained and very skilful special instructors. These comprehensive and costly improvements in medical education have commanded general approval; and the schools which have effected them have been supported by the sentiment of the medical profession and encouraged by liberal endowment. Legal education has also been immeasurably improved during the same period, partly by the action of the schools of law, and partly by state legislation and the influence of enlightened Bar Associations. Theological education has changed less than any other form of professional education during the period under consideration, 
I18 The Gains Made in Education

and three reasons may be given for its comparatively small growth. First, the requirements for admission to schools of theology before 1870 were much higher than those for admission to any other professional schools ; secondly, theological education has been terribly crippled by the unfortunate eleemosynary methods of recruiting the seminaries; and thirdly, denominational limitations have affected unfavorably both teachers and students. Preconceived notions are always to be avoided in any search for truth; but when the preconceived notions have attained in the mind of teacher or pupil a sort of unassailable sanctity, they become serious hindrances to educational progress.

Two other costly developments of 
The Higher Education of Women I I9

the past thirty years have influenced the whole course of education, from the primary school through the university. The first is the higher education of women, a development which has taken place within a single generation. There were detached and limited efforts toward that higher education before the Civil War, but the great development of the coeducational colleges and universities, and of the separate colleges for women has taken place since that revelation of the nation's capacities. The woman college graduate already affects favorably the education of children of all ages. She affects also the attitude of school committees, secondary school-trustees, and university trustees toward the institutions 


\section{I20 The Gains Made in Education}

in their charge; and she affects the practice of medicine. The women's colleges have already demonstrated that the capacity of women to profit by the best educational methods in the most difficult subjects is quite equal to that of men, so far as acquisition goes. They have also demonstrated that young women of fair physique may pursue a full college course, not only without impairing their health and strength, but with simultaneous gain in bodily vigor. These are extraordinary successes to be won in a single generation. Grave doubts exist, and will exist for at least another generation, concerning the effects of the higher education of women on marriage, child-bearing, and family life; and these effects will, of 
The Welfare of the Body I2I

course, be the final tests of the utility of the higher education of women. No nation can afford to have any considerable proportion of its more intelligent women disqualified for their natural and highest career by a misdirected training. Nothing but lives of strenuous activity and earnest service can justify the higher education for either men or women; and this activity and service should be for each sex the most characteristic, indispensable, and exalted of which the sex is capable, on the whole and in the long run. I need not point out that the higher education of women has involved a large increase of expenditure on education.

The second educational development felt along the whole line during the 
I2 The Gains Made in Education

period under consideration, is the increased attention given to the welfare of the body, and to athletic sports in schools and colleges. With characteristic American intensity these useful tendencies have been greatly exaggerated; yet incalculable good has resulted from them. That the attention of a community once Puritan or Calvinistic should be withdrawn from those Bible passages which express a deep sense of the vileness of the body, and should be turned toward those passages of opposite tenor which extol the holiness of our bodies, is certainly no misfortune. In the comparative abandonment of farm life a great variety of outdoor sports is necessary to defend society against bodily degeneration; 
but when one sees 35,000 people watching with intense excitement a game of football, one cannot but regret that the most violent and least generally useful of all the sports should possess greatest interest for the public, because of its quality as a rough and somewhat dangerous combat. But at such times one should remember that this is only the acme of a widespread, persistent interest in a variety of outdoor sports - a variety great enough to meet all sorts of tastes and capacities, and to draw hundreds of thousands of boys and girls, and men and women, into enjoyable exercises in the open air. Men and women who are to be devoted to the intellectual life especially need a sound physical training in youth, and an inextinguish- 
I24 The Gains Made in Education

able liking for out-of-door exercise; otherwise the steady drain on the nervous system which this class undergoes will make of it a physically weak and unproductive class, to the great loss of the community. The intercollegiate contests in sports, with their present elaborate organization and regular periodicity, are new phenomena in American education, and on their present scale are quite unknown in other countries. They are exaggerated in number, and in frequency of occurrence; and they have given rise to mischievous antagonisms between institutions whose relations should have been of the friendliest; but intercollegiate relations in athletic sports are gradually becoming fairer and more 


\section{Gains Approved Though Costly 125}

amiable than they used to be, and if these competitions cannot yet be considered one of the successes of American education, they need not be reckoned as one of its failures. Other intercollegiate contests have grown out of the competitions in athletic sports, and some of these have good effects. Thus it is a good effect of intercollegiate debating that it has distinctly promoted the careful study of history, economics, and current events. It is to be observed that this athletic development has been very costly, but that the cost is borne with satisfaction by the American public.

Every educational improvement of the past thirty years that I have mentioned has been costly; but every one 
126 The Gains Made in Education

has justified itself in the eyes of the taxpayers, or of those who voluntarily pay for it; not one would now be recalled, and the total result encourages the expectation that large new expenditures would commend themselves to the people at the start, and in the end would prove to be both profitable in the material sense and civilizing in the humane sense.

You have doubtless noticed that the gains I have reported are chiefly in education above fourteen years of age. There has been improvement in the first eight grades since 1870 , but it is relatively small. Yet the great majority of American children do not get beyond the eighth grade. Philanthropists, social philosophers, and friends of free 
Gains in Lower Grades Inadequate 127 institutions, is that the fit educational outcome of a century of democracy in an undeveloped country of immense natural resources? Leaders and guides of the people, is that what you think just and safe? People of the United States, is that what you desire and intend? 



\section{The Needs of American Public Schools}

[An address delivered before the Rhode Island Institute of Instruction, on October 23, 1902.] 



\section{NEW EXPENDITURE FOR SCHOOLS}

N October I7th I advocated before Connecticut teachers the expenditure of more money for education in the United States on the ground that the shortcomings and failures in American education, and the disappointments concerning its results, have been many and grievous; and on the next day I advocated before New Hampshire teachers increase of educational expenditure on the ground that many successes have been won by American schools and colleges, and that these successes, though involving in- 
I32 New Expenditure for Schools

creased expenditure, have been approved and rejoiced in by the American public. The first argument was an incitement to greater exertions, because of ill success, or of imperfect attainment of ends wisely sought; the second was an encouragement to greater expenditure because of the results achieved with the expenditure already made. To-night I wish to describe some of the objects for which increased expenditure should be made in the schools supported by taxation, and to adduce some further considerations fitted to encourage American communities to larger expenditure.

- The expenditure on school buildings has been generous during the last twenty years; but in two respects most of the buildings erected during this 


\section{Fire-proof School Buildings I33}

period have fallen far short of the proper standard. First, in cities and large towns all school buildings should be fire-proof, and particularly all halls and stairways should be fire-proof. Wooden staircases should be absolutely prohibited in schools intended for children under fifteen years of age. Secondly, the woodwork in the interior of school buildings should be reduced to the lowest terms, and should be carefully constructed with reference to the facility of keeping it clean, just as the woodwork in the interior of a modern hospital is constructed; and the materials of walls in school buildings should not be absorbent, but, on the contrary, should resist both moisture and gases, and should be capable of thorough 


\section{I34 New Expenditure for Schools}

cleansing. The last remark applies also to the heating apparatus for school buildings. All flues, ducts, and boxes for the reception and conveyance of cold or hot air should be so built and disposed that their interiors can be cleaned. Any one who has examined with a lens the extraordinary amount of animal and vegetable matter which accumulates on a sheet of "tanglefoot" fly-paper placed in a cold-air box, at any season of the year when the ground is not covered with snow, will heartily concur in this prescription. The observance of these rules would, of course, demand additional initial expenditure on school buildings, but would diminish the cost of maintenance. Again, whether in town or country, a 
large open space, yard, or garden should be connected with every school building, and should be kept neat, and decorated with shrubs and flowers. The denser the population in which the school is situated the greater the need of this open space; and the larger the school the larger should be the yard attached to the building. Here again is a call for a large additional expenditure; but it is an expenditure which the welfare of city children urgently demands. Every school should have the means of turning at least half its pupils into the open air simultaneously; and the space about the school should be so arranged that hundreds of children can occupy it without marring its decorative vegetation. This means, 


\section{I36 New Expenditure for Schools}

of course, that the greater part of every school yard should have a surface of gravel or asphalt. Such grounds could be made useful in crowded quarters to many people besides the school children. If it be urged that it is impossible in American cities to depend on the permanent occupation of any particular district by a population which needs schools, and therefore that the construction of durable schoolhouses and the provision of grounds about them are inexpedient, I reply that if a schoolhouse and its yard, once situated in the midst of a dense population, become unnecessary, it must be because the district has been abandoned as a residence quarter in favor of factories, shops, or some other sort of productive 
Medical Inspection of Schools I37

business; and, therefore, if the city has provided in such a district a large school yard, it will be able to compensate itself for the loss on its building by the rise in the value of its land.

Next to this improvement in schoolhouses and school yards comes improvement in the sanitary control and management of schools. This control requires the services of skilful physicians; and such a physician should be officially connected with every large school. It should be his duty to watch for contagious diseases, to prevent the too early return to school of children who have suffered from such diseases, to take thought for the eyes of the children, lest they be injured by reading or writing in bad postures or bad 


\section{I38 New Expenditure for Schools}

light, to advise concerning the rectification of remediable bodily defects in any of the children under his supervision, to give advice at the homes about the diet and sleep of the children whose nutrition is visibly defective, and, in short, to be the protector, counselor, and friend of the children and their parents with regard to health, normal growth, and the preservation of all the senses in good condition. Such medical supervision of school children would be costly, but it would be the most rewarding school expenditure that a community could make, even from the industrial or commercial point of view, since nothing impairs the well-being and productiveness of a community so much as sickness and premature disability. 
or death. As in an individual, so in a nation, health and strength are the foundations of productiveness and prosperity.

The next object for additional expenditure is better teachers. Of course, teachers should know well the subjects they are to teach; but that is by no means sufficient. Every teacher should also know the best methods of teaching his subjects. College professors heretofore have been apt to think that knowledge of the subject to be taught was the sufficient qualification of a teacher; but all colleges, as well as all schools, have suffered immeasurable losses as a result of this delusion. Of course, it is better for a 
I40 New Expenditure for Schools

teacher to know his subject without knowing the right method of teaching it, than to acquire a formal method without knowing the subject; because a conscientious teacher by experimenting on his pupils may in years acquire a good method at their expense; but teachers who are acquainted at the start with both subject and method are what schools and colleges urgently need. To secure this double proficiency means a greater expenditure on the training of teachers. Under the head of better teachers may best be mentioned certain specific desiderata such as a larger proportion of male teachers in urban school systems, a larger proportion of women teachers who have been educated at college, and a larger proportion of both men and 
women who have received a genuine normal school training. All these are expensive desiderata.

With better teachers, numerous other improvements would come in, as, for instance, a better teaching of literature and of history, and better biological and geographical instruction, these natural history studies being pursued by the pupils in the open air as well as in the schoolrooms. I have elsewhere urged that all public open spaces - country parks, forests, beaches, city squares, gardens, or parkways - should be utilized for the instruction of the children of the public schools by teachers capable of interesting them in the phenomena of plant and animal life. But this means quite a new breed of 


\section{New Expenditure for Schools}

common school teachers. The teaching of geography in the open air is a delightful form of instruction; but it requires a teacher fully possessed of the principles of physiography, and knowing how to illustrate these principles on a small scale in gutters, brooks, gullies, ravines, hillsides, and hilltops. Some naturestudy of this desirable sort has been already introduced into American schools; but it is not persisted in through years enough of the school course. Much more of this sort of study is needed, beginning in the kindergarten and going through the high school. Vacation schools can give this sort of instruction to great advantage. It must be confessed that it is an expensive kind of instruction; but this is one 
Fewer Pupils to a Teacher $\mathbf{I} 43$

of the places at which more money should be spent.

Given better teachers, the next additional expenditure should be due to a large reduction in the number of pupils placed before a single teacher. This number may now be said to vary from forty to sixty in the different school systems of the United States. The higher number is monstrous and the lower far too large. Twenty to twenty-five pupils to a teacher are quite enough, if there are to be secured an adequate degree of attention to the individual pupil and a proper classification of each - group of pupils according to their quality and capacity. This is an improvement very urgently needed in the American schools of to-day. It 
144 New Expenditure for Schools

would doubtless cost a good deal of money, but it would not necessarily double the item of salaries; for one competent teacher, with an intelligent though less experienced assistant, can take good care of forty pupils. When from forty to sixty pupils are allotted to a single teacher with no assistant, there is no opportunity for individual instruction; the whole group must move on together; and it is inevitable that the brighter pupils should be sacrificed to the duller, which is the most wasteful thing a school can do. The improvement of which I am now speaking would lift American education to quite another plane of efficiency, and would make the life of the teacher vastly more interesting, more rewarding, and 


\section{Pensions for Teachers}

happier. The personal contact between teacher and pupil would be more frequent and intimate, and the teacher's function would change from driving a flock to leading on and stimulating individuals.

In order to keep good a large staff of teachers employed by a city or town a system of retiring allowances for teachers is indispensable. It is the American practice to keep in office superannuated or partially disabled teachers who have served long and well, and to pay them their salaries until death or complete disability overtakes them. This practice is uneconomical, and very injurious to the children who come under the charge of such partially disabled or senile teachers. It 
I46 New Expenditure for Schools

is considerate toward the few veterans, but very inconsiderate toward the hundreds of children whose education is impaired. A proper pension system gives the managers of a school system the means of retiring such teachers, and of replacing them by fresh, wellselected appointees, without causing any hardships, or wounding any feelings. A good pension system is not expensive; for when an old teacher retires on an allowance the retirement will ordinarily give rise to several shiftings of place, and the vacancy really filled is one near the foot of the scale of salaries. There is a pension to pay, but there comes upon the pay-roll a newcomer's salary which is much smaller than the salary of the teacher of long service. Pensions, 
or retiring allowances, would not therefore be the cause of a large new expenditure, but would instead bring about a great increase in the competency or efficiency of any urban school system.

The universal employment of highly trained superintendents in both urban and rural systems is the next improvement of which I would speak. This improvement has been partially introduced; but it ought to become universal, and the quality of the superintendence should be always rising, until the position of superintendent shall be recognized as the highest in a school system, whether in city or country. A single superintendent can, of course, serve several rural districts or towns; and to obtain the right kind of superin- 
I48 New Expenditure for Schools

tendent such coöperation is necessary. In general, the aid of the State is also necessary to provide rural communities - with competent superintendents. Such superintendents should be entirely independent of political influences, and should enjoy a large measure of authority and freedom in their functions. They ought, as a rule, to be men or women of college education, who have had some experience themselves as teachers in schools or academies. The kind of superintendent that I have in mind is one who comes into immediate contact with both teachers and pupils. The wide-field superintendence, such as a state superintendent may exercise, is of course desirable; but such a remote official may not have the imme- 


\section{Business Agents}

diate good influence on the teaching, discipline, and business management of the schools which the rural superintendent and the inspector or supervisor in large city systems may exercise.

It is the man or woman who is constantly going about among the schools in his or her charge whose educational quality needs to be raised. The head of a state system, or of a large city system, is an administrator. The rural superintendent or city supervisor is primarily an inspector, teacher, and guide.

All business or executive functions ought to be withdrawn from the school committees or boards and handed over in part to the superintendent, and in part to a business agent, who, like the superintendent, is a permanent 


\section{I50 New Expenditure for Schools}

salaried officer. Since the present subcommittees of school committees or boards serve without pay, the salaries of these business agents would, of course, be an additional charge; but a competent and experienced agent, by conducting school business judiciously, will always save more than his salary, and will, moreover, greatly increase the wholesomeness and efficiency of the schools.

An expensive improvement in the public schools, but one urgently needed, is the enrichment of the school programme for the years between nine and fourteen, and the introduction of selection among studies as early as ten years of age. Unless this is done, and done soon, 


\section{Better School Programmes I5I}

the public schools will cease to be resorted to by the children of well-to-do Americans. The private and endowed schools offer a choice of foreign languages, for instance, as early as ten years of age and even earlier; and everybody knows that this is the age at which to begin the study of foreign languages, whether ancient or modern. In large cities it seems to be already settled that the private and endowed schools get the children of all parents who can afford to pay their charges. One reason for this result is that the programmes of the public schools are distinctly inferior to the programmes of the good private and endowed schools; and they are inferior at precisely this point-they have too limited 
I52 New Expenditure for Schools

a range of studies in the years between nine and fourteen. It is, of course, not desirable that each individual child should pursue a great variety of studies; but it is essential that each individual child should have access to a variety of studies. The tendency in all American school systems has been to segregate the foreign languages, the mathematics beyond arithmetic, and the higher scientific and historical studies in the high school programmes-which means that only that small proportion of children who go on to the high school have any access to those studies. No arrangement could possibly be more undemocratic; although its inventors did not foresee the real working of their method in this respect. The achievement of this 
enrichment of the programmes would cause the retention of children in school for a larger number of years, and the carrying forward of more children into the upper schools; and these are effects greatly to be desired. I am bound to acknowledge, however, that these changes would be decidedly costly; they would require more accomplished and more skilful teachers for the years between nine and fifteen, and more apparatus for teaching; and if they were successful there would be more children to teach in the upper grades of the system.

An incidental effect of these changes would be the development of departmental instruction-that is, skilful teachers would teach one subject 
I54 New Expenditure for Schools

through several grades, instead of teaching all subjects for one grade. It was in 1766 that Harvard College-then no more than a good high schoolabandoned the method of teaching all subjects to one class by one man. The American public school system bids fair to be nearly one hundred and fifty years behind Harvard College in adopting the departmental method-a method which develops in both teachers and pupils a growing interest in their work, and increases greatly the personal influence of teachers, because the staying pupils work through several successive years under the same teacher. Another effect of this enrichment of the programmes would be the postponement for every individual pupil of the 
grave decision between studies which permit access to the higher institutions of learning, and studies which do not. The later this decision can be made the better for the individual, and the better for the schools; because a course of study which is preparatory to all possible future routes in education is sure to be a better course than the poorer of two courses, one of which leads on to the higher institutions and the other does not.

The election of studies in secondary schools involves increased expenditure for two reasons: first, because there are more subjects to be taught; and, secondly, because each subject will be carried further than it is under a uniform prescribed course. Moreover, 
I56 New Expenditure for Schools

the classes in each subject will be smaller than they are under a prescribed system, because the total number of pupils will be divided among a larger number of subjects. The election of studies in secondary schools is already introduced in many places, generally under the form of several groups of studies bearing different names; but sometimes, as in Boston, in a frankly elective method. The experience of the American colleges in regard to the elective system demonstrates that it is much more costly than the prescribed; but it is also so much more effective for all educational purposes, whether mental or moral, that it advances steadily in all the faculties of arts and riences, and 


\section{Manual and Technical Training 157}

never takes a backward step. It may be safely assumed, therefore, that it will make steady progress in the secondary schools of the country, and with like results-greater cost, but greater profit.

In many scattered places in the United States perfect demonstration has already been given that manual training and instruction in the mechanical arts and trades are, in the first place valuable as means of mental and moral training, and in the second place useful for the individual toward obtaining a livelihood, and for the nation toward developing its industries. Accordingly, manual training schools, mechanic arts high schools and trade schools ought to become habitual parts 
I58 New Expenditure for Schools

of the American school system; and normal schools and colleges ought to provide optional instruction in these subjects, since all public school teachers ought to understand them. Such schools are more expensive than schools which do not require mechanical apparatus and the service of good mechanics as instructors; but there can be no doubt that they will repay promptly their cost to the community which maintains them.

Vacation schools have also demonstrated their great usefulness in cities and large towns. The best ones offer manual training for both boys and girls, as well as book work, and are heartily welcomed by both parents and children. They combat effectively the . 
mistaken policy of long vacations for children who cannot escape from the crowded city streets and tenements. Indeed, the experience recently gained in city vacation schools and in the summer courses of colleges and universities proves that the long summer vacation of nine to thirteen weeks is by no means necessary to the health of either school children or maturer students. The best method is to keep the pupil in vigor all the year by means of frequent recesses during school hours, free half-? days twice a week, and occasional respites of a week. Then the vacation school in summer should offer a distinct variety of work in subjects different from those pursued the rest of the year; for children and adults alike 
r60 New Expenditure for Schools

find great refreshment in mere change of work. For example, the competent college professor may, indeed, seek change of air and scene during the summer vacation, but it is for the purpose of doing under advantageous conditions a kind of intellectual work different from that which engrosses him in term-time, and not with the intention of keeping his mind vacant or inert. Furthermore, vacation schools in the poor quarters of closely built cities are downright refuges from the physical squalor and moral dangers of the streets. It is obvious that vacation schools on an adequate scale must cause a serious addition to the school expenditure of a city or large town; for they require the services of an 
More Attention to Drawing $\mathbf{1 6 \mathbf { I }}$

additional corps of teachers, and they need additional apparatus, materials, and service. It is equally obvious that these schools are urgently needed by a large proportion of the population on grounds which are simultaneously physical, mental, and moral. I say nothing here about the kindergarten, because, as I have twice pointed out of late, the kindergarten has already been somewhat extensively adopted as part of the public school system, and is winning more and more favor.

Another additional expenditure which public schools ought to incur as soon as possible is a development of instruction in drawing. Drawing is a mode of expression which ought to be as universal as writing. There is no art, trade, 
r62 New Expenditure for Schools

or profession in which it is not useful, and the enjoyment of life may be greatly increased by the habitual use of the pencil in sketching interesting objects of all sorts, natural or artificial. Time for drawing can be obtained in school programmes by diminishing the time given to penmanship. Instruction in one art will help the other, and of the two, drawing is the more instructive, since it trains the powers of observation, and helps to make the retained impressions both accurate and vivid. It is an incidental advantage of drawing that it reinforces the teaching of geometry, and particularly of solid geometry. The comparative neglect of geometry is one of the most curious phenomena in American education, 
when the importance of that subject in the mechanical and constructive arts in which Americans excel is duly considered.

Music is another subject which ought to be made much more of in all American schools, public, private, and endowed, than it now is. The elementary schools do more for music than the secondary schools; so that the course of musical instruction is broken off too early, and the skill gained before fourteen years of age is lost later through disuse. A moderate degree of musical knowledge and skill adds greatly to the enjoyment of life, no matter how the livelihood may be earned. To increase rational joy is one of the objects which public education should always keep 
I64 New Expenditure for Schools

in sight. I need not say that music has always been a true culture subject, an ally of literature, art, and religion.

Lastly, the schools ought to be provided liberally with all appliances which can improve either teaching or administration, and with all service which can relieve the teachers of unnecessary bodily or mental strains. Such appliances are books, maps, charts, models, diagrams, lantern-slides and electric lanterns, telephones, collections of specimens, physical and chemical apparatus, casts, photographs, pictures, typewriters and pianos. To try to teach without these aids is like trying to stop a conflagration with buckets passed from hand to hand, or like starting for Chicago in a one-horse chaise instead of 
More Appliances for Teaching $\mathbf{I}_{5}$

in the Empire State Express. The prevailing poverty of our schools in these respects is lamentable. At every stage of education, from the kindergarten through the university, an alert and progressive teacher can save his or her own time and energy by transferring the mechanical or routine parts of his or her work to an assistant who receives a much smaller compensation than the teacher. To save that valuable time and energy for the best work is the truest economy, yet this economy is seldom practised. In both these respects American schools fall far below the standards of well-conducted commercial and industrial establishments.

I have thus enumerated various 


\section{I66 New Expenditure for Schools}

ways in which a greatly increased expenditure on American schools ought to be made. This audience of teachers may perhaps have observed that I have not said a word about raising salaries. That is because I do not consider that direction the best one for additional school expenditure. The teacher needs many other things more than higher pay-good light and air to work in, medical inspection and care for the school, all available assistance in the schoolroom, all useful apparatus for teaching-particularly that which appeals to the eyes and fingers of the pupils-relief from mechanical and clerical work, a better tenure, a pension at disability, and expert instead of amateur supervision. And, on the other 


\section{Expenditure Should Be Doubled I67}

hand, the community needs to have the teacher a more intelligent, betterinformed, robuster, and gayer person, that children will "take to" and wish to please, and that parents will be glad to have visit them in their homes.

With these objects in view the expenditure in those parts of our country where it is now smallest ought to be raised as rapidly as possible to the level of those regions where it is now greatest; and in those regions where the expenditure is now most liberal it ought to be doubled as soon as possible.

I know that some people will say that it is impossible to increase public expenditure in the total, and therefore impossible to increase it for schools. I 


\section{I68 New Expenditure for Schools}

deny both allegations. Public expenditure has been greatly increased within the last thirty years, and so has school expenditure. What the country has done it can do again; and, furthermore, it can better its past record. Moreover, school expenditure ought to be increased, even though the total expenditures of the community should not rise; because it yields a greater return than any other expenditure. It is, indeed, far the most profitable of all the forms of public expenditure; and this is true whether one looks first to material prosperity, or to mental and moral well-being; whether one regards chiefly average results, or the results obtained through highly gifted individuals. 
The Test of Popular Education 169

But some sceptic may ask, how do we know that even the expenditure the country now makes for education is worth making? And again, how do. we know what the results of popular education are? What test is there for the efficiency of popular education? Let me try, in conclusion, to answer these grave questions.

In the first place, as I look back on the progress of American education since the Civil War, I think I see that education is the one agency for promoting intelligence and righteousness which has unquestionably gained power in the United States during the last half-century-the one agency which has not only retained its hold on the democratic masses, but has distinctly 
I70 New Expenditure for Schools

gained more and more public confidence, and received from the democracy greater and greater moral and material support. The democracy has believed more and more in the efficiency of schools and colleges; and schools and colleges have more and more taught and acted out democracy. This is only saying, on the one hand, that the popular masses perceive that it is in large part the schools and' colleges which implant in successive generations democratic ideals and make them fit to be free; and, on the other, that the schools and colleges believe in the democratic ideals, and fervently desire to promote brotherhood, unity, and the practical acceptance of the Pauline doctrine, "every one members one of 


\section{Less Respect for Legislatures I7 I}

another." Can we say of any other of the organized inspiriting and moralizing forces in American society that it has gained strength and increased its influence during the past fifty years? The efficiency of legislatures and the respect in which they are held have unquestionably declined since the Civil War. American legislative assemblies, municipal, state and national, have repeatedly shown themselves unable to solve, or even begin to solve, the new problems which have arisen in rapid succession out of the incredible changes in industry, commerce, and transportation. In other words, legislatures have not been able to keep up with American progress in other fields. 


\section{I72 New Expenditure for Schools}

Some of them have ceased in large measure to be deliberative assemblies, and habitually transact important parts of their business in secret committee meetings. Others have proved to be in the hands of one man, himself not a public official; so that legislation is adopted or rejected at that one man's will-sometimes a purchasable will. Congress has repeatedly disappointed the people in respect both to its intelligence and to its magnanimity; and with a rather piteous recognition of its own incapacity it has repeatedly taken refuge in the discretion of the Executive.

Most persons will also agree that the courts of our country are as a whole less efficient and less respected to-day than they were a generation or two 
generations ago. Their decline is painfully apparent in criminal mattersand is plainly visible in civil matters also. The efficacy of the death penalty has been well-nigh destroyed by the delays ordered or permitted by courts. The courts often seem embarrassed by conflicting precedents or contradictory decision, and paralyzed by multiplying technicalities and ingenuities of counsel. Moreover, they not infrequently give uncertain sounds. Hence reverence for law is not maintained at its old level; and lawless violence against suspected criminals claims justification in the delays and uncertainties of legal processes.

The church and its ministers cannot be said to have risen in public estima- 
I74 New Expenditure for Schools

tion since the Civil War. Its control over education has distinctly diminished. In some of its branches it seems to cling to archaic metaphysics and morbid poetic imaginings; in others it apparently inclines to take refuge in decorums, pomps, costumes, and observances. On the whole, it has not been able to keep up with the progress of either science or democracy-those Atalantas of the nineteenth century that never stop for golden apples dropped in their path-and it has shown little readiness to rely on the intense reality of the universal sentiments to which Jesus appealed, or to go back to the simple preaching of the gospel of brotherhood and unity-of love to God and love to man. So the 
church as a whole has to-day no influence whatever on many millions of our fellow countrymen-called Jews or Christians, Protestants or Catholics, though they be. We still believe that the voluntary church is the best of churches; because a religion which is accepted under compulsion is really no religion at all for the individual soul, though it may be a social embellishment, or a prop for the State. Yet, believing thus, we have to admit that the voluntary church in the United States has no hold on a large and increasing part of the population.

By no positive fault of their own, but by a sort of negative incapacity, legislature, court, and church seem to be passing through some transition 
I76 New Expenditure for Schools

which temporarily impairs their power; but the schools and colleges in the United States, while changing and developing rapidly, have suffered no impairment of vigor or influence. On the contrary, education as an uplifting agency was never so effective with the democracy as it is to-day. To redeem and vivify legislatures, courts, and churches, what agency is so promising as education? Next to steady productive labor education is the prime factor in social and industrial progress. This primacy of education among the various civilizing factors affords the strongest possible inducement to spend every dollar on popular education which can be spent advantageously. It also gives an answer, 


\section{The Primacy of Education}

drawn from experience, to the question -is the present expenditure worth making? A reasonable foresight supplies another answer. We should ask ourselves-what better remedy than wise popular education, what other thorough remedy, can be imagined for the new evils which threaten society because of the new facilities for making huge combinations of producers or middlemen, of farmers or miners or manufacturers, of rich or poor, of laborers or capitalists? Masses of men are much more excitable than average individuals, and will do in gregarious passion things which the individuals who compose the masses would not do. A crowd is dangerously liable to sudden rage or-what is worse-sudden 


\section{I78 New Expenditure for Schools}

terror; and either emotion may overpower the sense of responsibility, and annihilate for the moment both prudence and mercy. There never was a time when common sentiments and desires could be so quickly massed, never a time when the force of multitudes could be so effectively concentrated at a selected point for a common purpose. Against this formidable danger there is only one trustworthy defense. The masses of the people must be taught to use their reason, to seek the truth, and to love justice and mercy. There is no safety for democratic society in truth held, or justice loved, by the few; the millions must mean to do justly, love mercy, and walk humbly with their God. The millions must be 
taught to discuss, not fight; to trust publicity, not secrecy; and to take timely public precautions against every kind of selfish oppression. To give this instruction steadily and universally society possesses no organized agency which compares in present efficiency and future promise with the schools. Therefore, the present expenditure on schools is fully justified and increased expenditure urgently demanded. I can almost hear the objection-this expectation of popular schools is extravagant -they are only for teaching reading, writing, and ciphering. Not so, I reply. The common schools should impart the elements of physical, mental, and moral training, and in morals the elements are by far the most valuable part. 
I80 New Expenditure for Schools

Secondly, let me deal briefly with our sceptic's demand for a test of the results of popular education. I think there must be some sure-working practical tests of the efficiency of popular education. Can they be stated? Concerning an educated individual, we may fairly ask, can he see straight? can he recognize the fact? Next, can he draw a just inference from established facts? Thirdly, has he self-control? or do his passions run away with him? or untoward events daunt him? These are fair tests of his mental and moral capacity. One other test we may fairly apply to an educated individual-does he continue to grow in power and in wisdom throughout his life? His body ceases to grow at 
Lifelong Increase in Wisdom $18 \mathrm{I}$

twenty-five or thirty years of agedoes his soul continue to grow? It is obvious that these tests are difficult of application to a nation; but we are not wholly without means of applying them to our own people as a mass. The people live by agriculture, mining, and manufacturing; and these great concerns cannot be successfully managed unless multitudes of men recognize essential facts, and draw the right inferences from the truths they embody.

The success with which the American people get their livelihood shows that there is much soundness in their mental training. Millions of them must be able to observe accurately and to infer justly. One of the most difficult tasks for a man who thinks imperfectly is to 
I82 New Expenditure for Schools

get over a delusion. Whenever the American people through the reasoning power of millions get over a delusion, they shed light on the efficiency of their own education. We have had a recent piece of evidence of this sort in the recovery of our people from the widespread silver delusion. Do their passions run away with the people? They did not after the Civil War, the forbearance of the Confederates being as remarkable as that of the Unionists. They did not at the close of the fighting with the poor Spaniards in Cuba. Never were terms of surrender more generous, or, I may add, more ingenious. The same self-control was manifested in the intelligent withdrawal of our soldiers from China. Do untoward 
events daunt the people? No. As a rule, our population bears calamities and losses with constancy and calmness. The country lately lost its singularly beloved Chief Magistrate, and lost him in an intensely mortifying way; but our Government never staggered even for a moment, and the whole work ard life of the people went on without a halt, or even a quiver, except for the momentary thrill of horror and humiliation. In the recent coal strike, which doubled the price of a necessary of life and caused widespread injuries and anxieties, the attitude of the muchenduring public was calm and discreet. The public took sides with neither party, looked on quietly at the irrational strife, accepted no bad advice, tried 


\section{I84 New Expenditure for Schools}

no unconstitutional remedies-just bore the losses, and waited five months for the combatants to accept that method of inquiry, discussion, and mutual consideration which ought to have been adopted when the conflict first arose. The strike has furnished a good illustration of popular self-control under very irritating conditions. Such are some of the indications that American education has not wholly failed of its high object.

Can we apply to the education of the nation the ultimate test which we finally apply to the education of an individual? As the national life grows broad and rich does the national soul or spirit grow with it? Does mental and spiritual progress keep pace with ma- 
The People Rise to Higher Work 185

terial? God only knows; but mortals may discern some facts which make toward the conclusion we should all like to establish. Thus, in regard to the mental powers of the population, whenever new machines, be they reapers, looms, cranes, crucibles, guns, or electric motors, have required more intelligent men behind them, the nation has invariably supplied on demand the needed men. This evidence is furnished incessantly on an immense scale, and it signifies that the people rise to their higher work. When a quiet villager, who has been just caring for his farm and his sawmill, is made school agent or chairman of the Board of Health, and is forced to think of all the children in the town, or of all the sick in it, 
I86 New Expenditure for Schools

if he does his work well, grasps ideas novel to him, and by energetic and judicious action spreads them through the town, we say that he has grown to his enlarging work. On a higher plane, that is just what we do say of Benjamin Franklin and Abraham Lincoln. In like manner the American people has grown to its expanding and novel industries, arts, and commerce, and has clearly done its daily work better than the competing nations. Hence, the total training of its youth, an important part of which has been given by the schools and colleges, must have been measurably successful.

The extraordinary sale of dictionaries and encyclopedias in the United States demonstrates the existence in innumer- 
able households of the habit of looking up the meaning of words, and the facts about unfamiliar topics encountered in conversation or in reading. This habit implies a lifelong desire to learn. The reading habits of the people prolong mental activity and growth, widen interests, and quicken sympathies; for the great mass of the people's reading matter is pure and instructive, in spite of the mortifying fact that parts of most daily newspapers are given over to Cloacina and the Furies.

But all this refers to the national mind applied to things material, or to the ordinary plane of commonplace life. How about things spiritual, the great moral movements, and the refinements and adornments of life? Is there 
I88 New Expenditure for Schools

any better test of unselfish and gentle feeling in a multitudinous people than their habitual treatment of women and children? Now, on the whole, Americans of all classes treat their women in large things and small better than any other people treat theirs. American men are laughed at by foreigners for making their wives and daughters extravagant and selfindulgent. On farms the women do not work in the fields as all foreign peasant women do. For factories we have in many states protective legislation in regard to the employment of women and children. There is a very significant difference between the expectation on the part of the American people of personal purity and domestic honor in 
Treatment of Women and Children 189

their public men, and the expectation in those regards on the part of any European people concerning their kings, princes, and high officials. The politician who disappoints the American people in that respect is lost, be he ever so serviceable a person. As to the treatment of children, it is certain that the discipline in American families and schools is gentler and more considerate than in other countries. Moreover, there has been a great advance in this respect within thirty years, an advance which has made the whole people happier and better. This is a widespread gain, made in millions of homes and schools; and it not only tells on the present moral condition of our people, but is of the highest promise for the 


\section{New Expenditure for Schools}

future. Somehow slavery is gone and intemperance has been checked and made disgraceful. The results testify to the moral forces which produce them.

If one would estimate the progress of a people in the fine arts and in science, one must go to the works of the few men who best illustrate the national art and science. In the whole history of sculpture can any one point to a more informing, inspiring, and touching military monument than the Shaw monument on Boston Common? There are bigger and costlier; but none more expressive, juster, or more uplifting. Look through the whole list of astronomical observatories since such establishments existed and you will not find one which, in proportion to its 
resources, has produced so much routine work and made so many new discoveries as the Harvard College observatory under its present director. In the prompt and general application of scientific discovery to the service of humanity Americans certainly excel other nations. It is enough to mention anesthesia, the telegraph, the telephone, and the innumerable inventions of labor-saving machinery. The use made of riches is another test of the moral condition and standards of a people. Now, the stream of gifts from private persons to schools, colleges, universities, libraries, art galleries, museums, and laboratories in the United States flows in a volume which has never been approached in the history 
192 New Expenditure for Schools

of the world. It is said that there are only six towns in all Massachusetts the inhabitants of which have no access to free books. It is not only the few very rich men who provide educational endowments. Every year thousands of Americans take part in this most intelligent beneficence, wiser than any endowment of hospitals, asylums, or infirmaries, because a work of construction instead of palliation. Truly there are some encouraging evidences that the soul of the people keeps growing.

So, in good heart and hope, learning from failures what not to do, and from successes what next to attempt, we may all press on together toward our national goal-the perfecting of an 


\section{The National Goal}

intelligent individual citizenship in a Christian democracy.

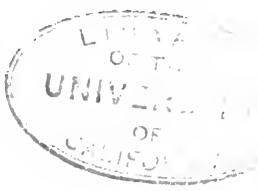







\section{.}


RETURN TO the circulation desk of any University of California Library or to the

NORTHERN REGIONAL LIBRARY FACILITY Bldg. 400, Richmond Field Station

University of California

Richmond, CA 94804-4698

ALL BOOKS MAY BE RECALLED AFTER 7 DAYS

2-month loans may be renewed by calling

(415) 642-6233

1-year loans may be recharged by bringing books to NRLF

Renewals and recharges may be made 4 days prior to due date

\section{DUE AS STAMPED BELOW}

\section{0}

JUN 08 1994

\section{RECEIVED}

\section{JUN 131994}

CIRCULATION DEPT. 


\section{YB 04394}

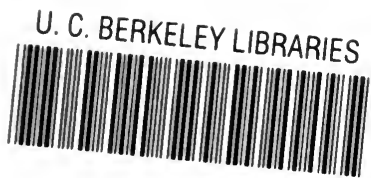

C046780199

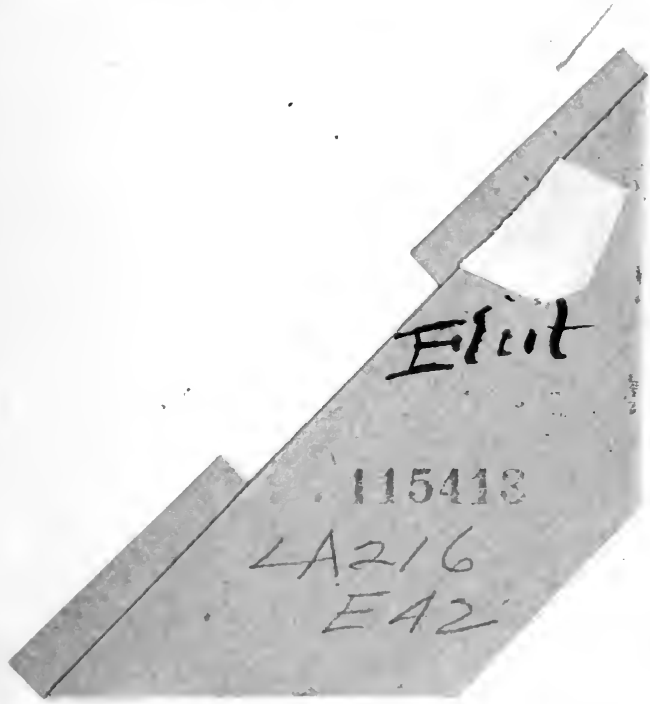


